\title{
Organization of Long-Range Inhibitory Connections within Rat Visual Cortex
}

\author{
Colin T. McDonald and Andreas Burkhalter \\ Departments of Neurology and Neurological Surgery, and Anatomy and Neurobiology, Washington University School of \\ Medicine, St. Louis, Missouri 63110
}

\begin{abstract}
We have studied the laminar organization of local long-range inhibitory connections within rat primary visual cortex (area 17) by combining retrograde tracing of nerve cell bodies with glutamic acid decarboxylase immunocytochemistry. While most inhibitory connections are confined to within $0.4 \mathrm{~mm}$ of the injection site, a subset of neurons at the layer 5/6 border provide long-range (>1 mm) inhibitory connections within area 17 . However, other cell layers that contain similar local long-range horizontal connections, that is, lower layer 2/3, upper layer 5, and lower layer 6 (Burkhalter and Charles, 1990), show a much more restricted distribution of inhibitory connections. This suggests that cells at the layer $5 / 6$ border play a role in the direct inhibition of neurons at a distant point of the topographic map.

Similar double labeling studies reveal long-range inhibitory connections between visual areas. Following injections of fluorescent tracers into area 17 , in horizontal sections inhibitory connections can be identified that are up to $8 \mathrm{~mm}$ long, linking the extrastriate subdivisions $18 \mathrm{a}$ and $18 \mathrm{~b}$ with striate cortex. Conversely, injections of fluorescent tracers into the cytoarchitectonic subdivision 18a reveal local longrange inhibitory connections within 18a, long-range inhibitory connections between $18 \mathrm{a}$ and the cytoarchitectonic subdivision $18 \mathrm{~b}$, and inhibitory forward connections from area 17 to $18 \mathrm{a}$. These results suggest that the communication between different cortical areas can be influenced by direct inhibitory connections.
\end{abstract}

[Key words: intracortical connections, glutamic acid decarboxylase, visual cortex, rat, intracortical inhibition, GABAergic connections]

The action of inhibitory neurons is critical for the function of cerebral cortex. This notion derives from single-unit recordings in visual and somatosensory cortex during blockade of GABAergic neurotransmission, which showed dramatic effects on the structure and selectivity of sensory receptive fields (Sillito, 1975a,b, 1977, 1979; Tsumoto et al., 1979; Dykes et al., 1984; Alloway et al., 1989). It is well documented that these inhibitory

\footnotetext{
Received June 17, 1992; revised Aug. 10, 1992; accepted Aug. 25, 1992.

We thank David Gottlieb for the generous gift of GAD-6 antibody. We are grateful to Randy Johnson for comments on the manuscript and to Steve Mitan for excellent technical assistance. Thanks also to Katharine Altemus, Deborah Hamilton, Györgyi Szebenyi, and John Wall for their contributions to earlier stages of the project.

Correspondence should be addressed to Andreas Burkhalter, Department of Neurology and Neurological Surgery, Box 8057, Washington Universił- School of Medicine, 660 South Euclid Avenue, St. Louis, MO 63110.

Copyright (c) 1993 Society for Neuroscience $0270-6474 / 93 / 130768-14 \$ 05.00 / 0$
}

inputs originate from within the cortex and do not arise from the thalamus (Montero and Zempel, 1985; Gabbott et al., 1986; Montero, 1986). In visual cortex of mammals, approximately one-fifth of all neurons are GABAergic and can be stained with antisera against $\mathrm{GABA}$ or its biosynthetic enzyme, glutamic acid decarboxylase (GAD; Lin et al., 1986; Meinecke and Peters, 1987). Although this population of neurons uses the same transmitter, the cells have different morphologies (Peters et al., 1982; Somogyi et al., 1984; Somogyi and Hodgson, 1985; Somogyi and Soltesz, 1986), colocalize different peptides (Hendry et al., 1984), stain for different calcium binding proteins (Hendry et al., 1989), and express different cell surface molecules (Naegele and Katz, 1990; Zaremba et al., 1990). This diversity suggests that different GABAergic cell types are integrated into different functional circuits: cells with short $(<400 \mu \mathrm{m})$ axons such as chandelier cells, spiderweb cells, and multipolar cells may participate in short-distance interactions, whereas cells with longer $(>400 \mu \mathrm{m})$ axons, such as bitufted cells and basket cells, may mediate interactions across different layers (Kisvarday et al., 1987) or between different cortical columns (Asanuma and Rose, 1973; Hess et al., 1975; Martin et al., 1983; Hata et al., 1988).

Considering the importance of inhibitory mechanisms, relatively little is known about the laminar origin and the vertical and horizontal organization of intracortical GABAergic connections, and our understanding is derived mainly from Golgistained projections of nonpyramidal cells. Although this has provided important insights into the arrangement of putative inhibitory connections (Jones, 1975; Valverde, 1976; Lund, 1987; Lund et al., 1988), there is reason to believe that the picture is incomplete because the Golgi technique only stains a small portion of the axonal arbor. Several studies, therefore, have taken an alternative approach and have used retrograde tracing of local connections with ${ }^{3} \mathrm{H}-\mathrm{GABA}$. They showed that the majority of inhibitory connections are contained within single vertical columns (Somogyi et al., 1983a; DeFelipe and Jones, 1985) and that very few connections extend horizontally, parallel to the pial surface. The only exceptions were neurons in layers 5 and 6 that project within their home laminae. Subsequently, however, it was shown that some ${ }^{3} \mathrm{H}-\mathrm{GABA}-$ labeled neurons did not stain with an antibody against GABA (Kisvarday et al., 1986), making it difficult to interpret the results obtained with the "transmitter-selective" (Streit, 1980) labeling technique. Because of these limitations, we have reinvestigated the organization of local GABAergic connections within rat visual cortex. For this purpose, we have combined GAD immunocytochemistry with retrograde tracing with fluorescent beads (Katz et al., 1984; Katz and Iarovici, 1990), which are known to label neu- 

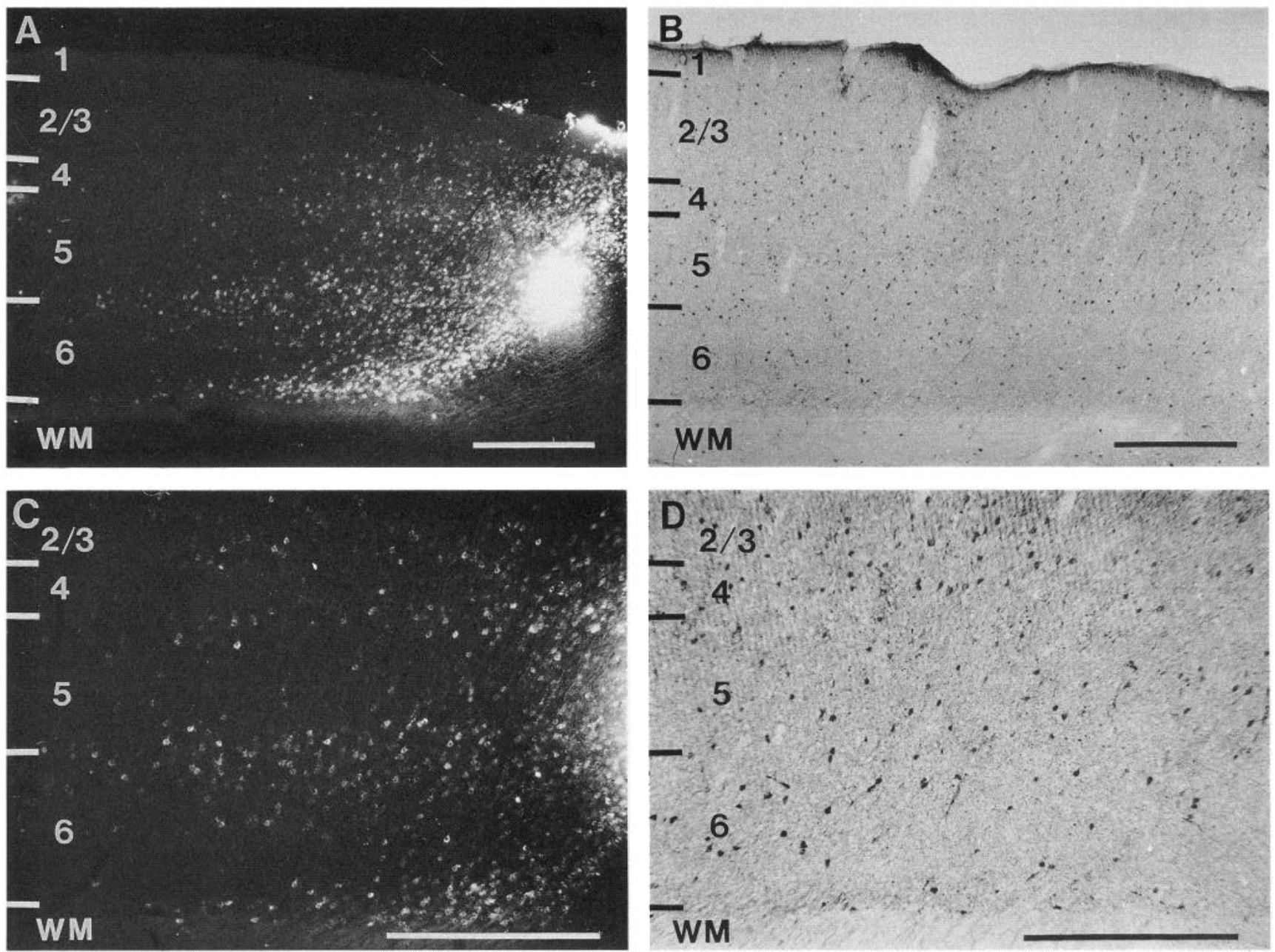

Figure 1. A, Fluorescence photomicrograph of parasagittal section through rat area 17 , showing distribution of neurons that are retrogradely labeled with beads via local axon collaterals. Brightly labeled column represents injection site that is centered in layer 5 , but involves layers $2 / 3-$ 6. Most cells are within $\sim 0.4 \mathrm{~mm}$ of the edge of the injection track. Many cells in layers $2-6$ are distributed more widely. Cells with the most extreme tangential spread tend to lie at the bottom of layer $2 / 3$ and the superficial and deep parts of layers 5 and 6 . Anterior is to the left. $B$, Photomicrograph of GAD-immunoreactive neurons in area 17. Darkly stained neurons are distributed throughout all layers. $C$, Higher-power view of local labeling after a bead injection into area 17 (section adjacent to that shown in $A$ ). Retrogradely labeled neurons at bottom of layer $2 / 3$ and top and bottom of layers 5 and 6 show widespread horizontal distribution. $D$, GAD-stained neurons and puncta in section adjacent to that shown in $C$. Notice that GAD-positive neurons and puncta can be detected in close proximity to the injection site (right margin; see $C$ ), suggesting that immunolabeling is unaffected by local injury. Scale bars, $0.5 \mathrm{~mm}$.

rons in nonselective fashion via local axon collaterals (Burkhalter and Charles, 1990).

Some of these findings have been published in abstract form (McDonald and Burkhalter, 1990).

\section{Materials and Methods}

A total of 38 3-5-week-old Long-Evans rats (75-150 gm body weight) were used in the experiments described here. Our basic strategy was to trace projection neurons retrogradely and to label these neurons immunocytochemically with antibodies against GAD. Local projection neurons within area 17 were labeled by injecting fluorescent latex microspheres (beads; Lumafluor, New City, NY; Katz et al., 1984; Katz and Iarovici, 1990) into area 17 and retrograde labeling of neurons though local axon collaterals. Area 17 injections were employed to reveal neurons that project from extrastriate cortex back to area 17. Injections into the cytoarchitectonic subdivision $18 \mathrm{a}$ in lateral extrastriate cortex were performed to visualize area 17 neurons that make forward projections to extrastriate cortex. Specific extrastriate areas were identified by retrograde labeling of callosal projections with bisbenzimide, and by using this pattern in conjunction with myeloarchitectonic features to delineate areal boundaries (Olavarria et al., 1987; Thomas and Espinoza, 1987).

Injections. To examine the local projections of GABAergic neurons within striate cortex, 26 rats received a single injection of rhodamineor fluorescein-labeled beads into area 17. For this purpose animals were anesthetized with pentobarbital $(40 \mathrm{mg} / \mathrm{kg}$, i.p.) and secured in a head holder. A small hole was drilled in the skull $(3.5 \mathrm{~mm}$ lateral to midline, $0.5 \mathrm{~mm}$ anterior to lambda suture) overlying striate cortex. A glass micropipette (tip diameter, 20-30 $\mu \mathrm{m}$ ) filled with beads was then lowered through this hole, and small volumes $(0.05 \mu \mathrm{l}$ each) of beads were deposited in the brain, $0.5-1.5 \mathrm{~mm}$ below the pial surface, by applying pressure to the back of the pipette using a Picospritzer (General Valve). This resulted in injection sites that extended throughout the thickness of cortex (Fig. 1A). After 2-4 d, animals were deeply anesthetized ( 80 $\mathrm{mg} / \mathrm{kg}$ ) and perfused through the left ventricle with $0.1 \mathrm{M}$ phosphate buffer (PB) followed by periodate-lysine-paraformaldehyde fixative (PLP; McLean and Nakane, 1974). The brain was removed from the skull and postfixed for $1 \mathrm{hr}$ in the PLP solution. Subsequently, coronal or parasagittal sections were cut on a Vibratome at $40 \mu \mathrm{m}$.

Interareal projections were examined in 12 cases. In six animals the left area 17 was injected with beads (see above) to label neurons in the cytoarchitectonic subdivision $18 \mathrm{a}$ that project back to area 17 . A second 


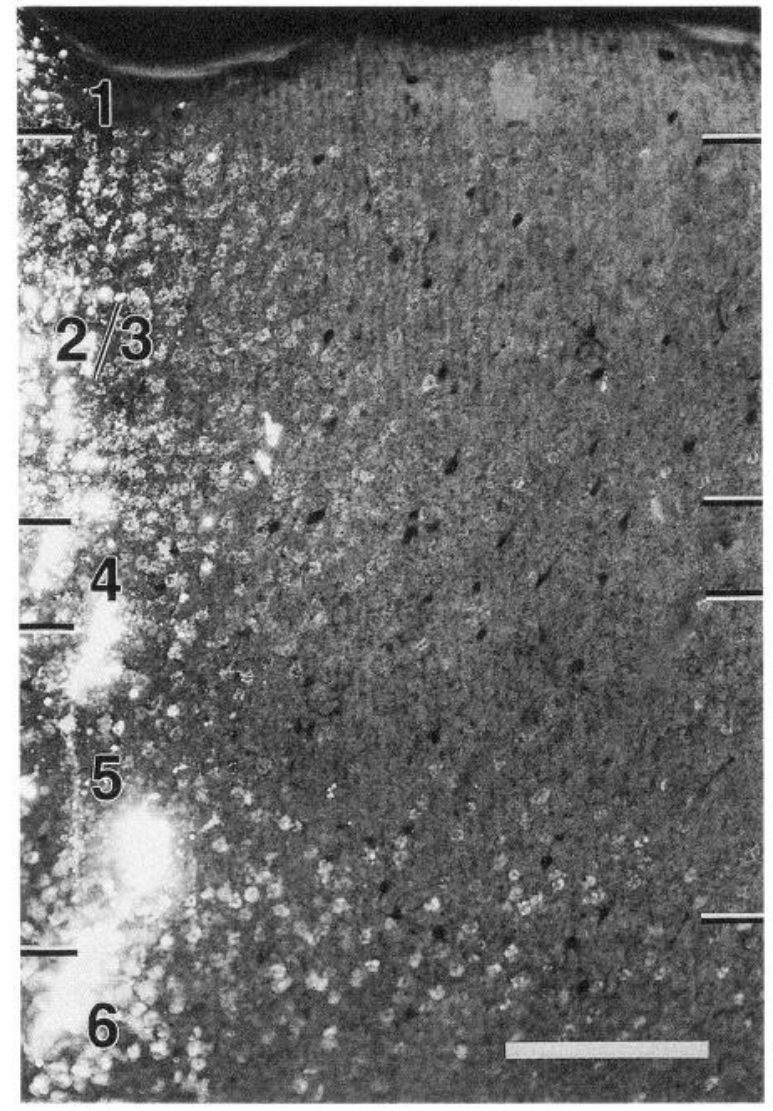

Figure 2. Fluorescence photomicrograph of local bead labeling in GADimmunostained parasagittal section through area 17 of rat visual cortex. Retrogradely labeled neurons are recognized by bright punctate bead labeling. Vertical column of bright clumps of beads at the left margin represents injection site. Notice that under epifluorescence illumination GAD-stained neurons appear as darkly stained profiles in the background. Anterior is to the left. Scale bar, $0.2 \mathrm{~mm}$.

group of six animals was used for bead injections into $18 \mathrm{a}(5 \mathrm{~mm}$ lateral to midline, $1 \mathrm{~mm}$ anterior to lambda suture) to label forward-projecting cells in area 17. In both groups of animals, bead injections into the left hemisphere were combined with $20-30$ bisbenzimide injections ( $10 \%$ in $\mathrm{H}_{2} \mathrm{O}, 0.05 \mu \mathrm{l}$ each) into the right occipital cortex to label callosal projections. After 2-4 d, animals were perfused with PLP fixative. Subsequently, the brain was removed from the skull and the cortex was separated from the rest of the brain and flattened between glass slides (Welker and Woolsey, 1974) in PLP fixative for $\sim 1 \mathrm{hr}$. Flattened cortices were viewed under UV illumination to reveal the bisbenzimide-labeled callosal projection pattern, and photographed using a low-power stereomicroscope equipped with epifluorescence optics. The tissue was cut on a Vibratome in the tangential plane at $40 \mu \mathrm{m}$

Immunocytochemistry. For colocalizing GAD in bead-labeled neurons, we used immunoperoxidase and immunofluorescence techniques. Both of these approaches are complementary, and each has its strengths and weaknesses: the immunoperoxidase procedure revealed more GADlabeled neurons but the reaction product tended to quench fluorescent beads, whereas the immunofluorescence procedure labeled fewer neurons, but double-labeled cells were easier to see. A quantitative comparison of the two approaches showed that the immunoperoxidase technique revealed, on the average, $\sim 25 \%$ more double-labeled cells. Thus, in most cases GAD was visualized with the immunoperoxidase technique. However, each finding was double checked with at least two experiments in which immunofluorescence was used.

For the immunoperoxidase reaction, floating sections were washed in PB and placed for $\sim 1 \mathrm{hr}$ in $10 \%$ normal horse serum in PB. Sections were incubated for $12-18 \mathrm{hr}\left(4^{\circ} \mathrm{C}\right)$ in a 1:4000 dilution of the monoclonal antibody GAD- 6 directed against the $59 \mathrm{kDa}$ band of the GAD protein (Chang and Gottlieb, 1988). Subsequently, sections were washed in PB and incubated in biotinylated horse anti-mouse IgG (1:200 in PB; Vec- tor) for $90 \mathrm{~min}$ at room temperature. After a final wash in $\mathrm{PB}$, the antigen was visualized using the Elite $\mathrm{ABC}$ immunoperoxidase technique (Vector). Sections were mounted on gelatinized slides, air dried, dehydrated in absolute alcohol $(30 \mathrm{sec})$, cleared in xylene $(30 \mathrm{sec})$, and coverslipped with Krystalon (Harleco).

For immunofluorescence, floating sections were incubated in a 1:2000 dilution of GAD-6, followed by 1:100 dilution of biotinylated secondary antibody. Texas red-labeled streptavidin $(1: 100)$ was used to visualize the antigen. Sections were coverslipped in PB containing $p$-phenylenediamine $(0.01 \%)$ to retard photobleaching.

GAD-6 (Chang and Gottlieb, 1988) was chosen as the primary antibody following a quantitative comparison of cell body staining with the anti-GAD antiserum raised by Oertel et al. (1981) and the polyclonal antibody against GABA (Immunonuclear), which both had slightly lower sensitivity. The PLP fixative was chosen over several paraformaldehyde solutions alone $(4 \%, 2 \%$, or $1 \%)$ or in combination with glutaraldehyde $(0.1 \%, 0.2 \%)$ based on its superior ability to reveal GAD-6labeled neurons. Addition of $0.1-0.3 \%$ Triton X-100, saponin, or digitonin to the primary antibody solution led to a decrease in cell body staining, and so detergents were not employed. Finally, the elite ABC peroxidase technique was judged to reveal approximately twice as many GAD-6-labeled neurons than the use of Texas red-labeled streptavidin to detect the biotinylated secondary antibody.

Scoring. The distribution of bead-labeled, GAD-immunoreactive $(\mathrm{GAD}+$ /bead) neurons was studied by first tracing sections including blood vessels, etc., under a stereomicroscope with a drawing tube attachment at $40 \times$. Sections were then examined under a fluorescence microscope equipped with rhodamine and fluorescein optics. In the immunoperoxidase-stained material, double-labeled neurons were recognized by switching between fluorescence and bright-field illumination. In the immunofluorescent material, double-labeled cells were detected by switching between rhodamine (GAD) and fluorescein (beads) optics. In both cases GAD+/bead cells were identified by the presence in the same focal plane of multiple clusters of beads in immunoreactive cell bodies. The distribution of GAD+/bead cells was scored onto the tracings, using blood vessels as reference markers. To assess the percentage of GAD-labeled projection neurons relative to the total number of projection neurons, GAD+/bead and bead-only cells were counted in a $100-\mu \mathrm{m}$-wide column that contained all layers of cortex. Average numbers were obtained from three sections: one centered at the injection site, and two displaced $100-200 \mu \mathrm{m}$ on each side of the injection center. Layers (Krieg, 1946) were determined from alternate sections stained for Nissl substance, or counterstained with bisbenzimide $(0.0001 \%$; Schmued et al., 1982) to reveal nuclei under UV fluorescence illumination. The same coronal sections also served for identification of the cytoarchitectonic borders of area 17 . In horizontal sections, the boundaries of area 17 were determined by its distinctive myeloarchitecture (see Fig. 6A,B; Olavarria et al., 1987). For this purpose sections were mounted in PB and photographed under dark-field illumination. Subsequently, immunostained sections were projected onto photographs of the myelin pattern, using blood vessels as landmarks. Extrastriate cortical areas were identified with reference to the callosal labeling pattern (see Fig. 6C,D; Olavarria and Montero, 1984; Thomas and Espinoza, 1987).

\section{Results}

\section{Inhibitory connections within area 17}

Injections of fluorescent beads into area 17 produced vertically elongated injection sites that spanned all layers. In some cases they were solid cylinders with diameters of 75-150 $\mu \mathrm{m}$; in other cases they were broken up into $\sim 50-250-\mu \mathrm{m}$-wide clumps (Figs. $1 A, 2)$. Each injection revealed a stereotypical distribution of bead-labeled cells (Fig. $1 \mathrm{~A}$; see also Fig. $5 \mathrm{~A}$ ) that was dependent on the depth of the injection only. In layer 1, labeled neurons were confined to the immediate vicinity of the injection site. Similarly, in layer 4 and the middle of layer 6 , the majority of labeled cells were confined to a relatively tight column around the injection track, whose diameter in the parasagittal plane was $0.4-0.8 \mathrm{~mm}$. By contrast, the distribution in layers $2 / 3,5$, and 6 was more widespread and labeled cells were found up to 1.6 $\mathrm{mm}$ from the margin of the injection site. Typically, the spread was greatest in the lower half of layer $2 / 3$ and at the top and 

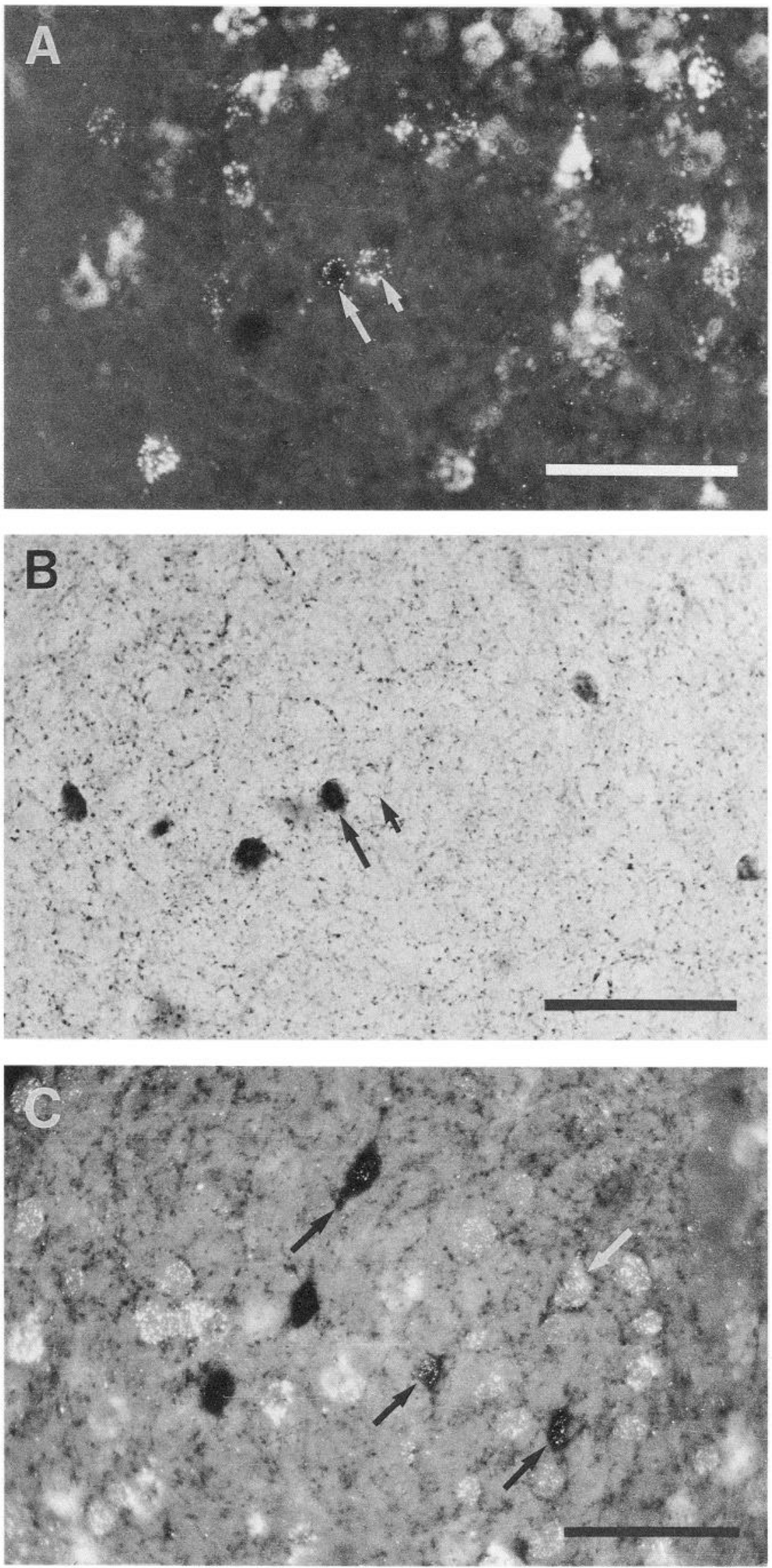

Figure 3. Fluorescence photomicrographs of GAD immunoperoxidasestained local projection neurons in area 17. Neurons are fluorescently labeled with beads after injection into area 17 and retrograde transport of the tracer via local axon collaterals. Parasagittal sections. A, Fluorescence photomicrograph of bead-labeled neurons. Dark profiles in background represent GADlabeled neurons. Cell indicated with large arrow is labeled with beads and expresses GAD immunoreactivity. Double-labeled cell resides in layer 3, $\sim 0.5 \mathrm{~mm}$ from margin of injection site. $B$, Bright-field photomicrograph of section shown in $A$. Large arrow points to GAD-positive cell that is also labeled with beads (see $A$ ). Notice that although $A$ and $B$ are in the same focal plane, GAD-labeled profiles in $A$ appear out of focus compared to $B$. The difference is due to the different modes of illumination: epifluorescence optics in $A$, bright-field illumination in $B$. Short arrow points to ring of GAD-positive puncta that appear to surround the beadlabeled cell shown in $A$ (short arrow). $C$, Photomicrograph taken under simultaneous fluorescence and bright-field illumination. In this rare case, the fluorescence signal was intense enough to reveal labeled beads in darkly GADimmunoreactive cells (black arrows). All of these double-labeled neurons lie along the layer $5 / 6$ border, $\sim 0.6 \mathrm{~mm}$ from the margin of the injection site. Notice that due to the nonuniform subcellular distribution of beads, the outlines of double-labeled cells seen under fluorescence and bright-field illumination often appear slightly different. White arrow points to bead-labeled pyramidal cell that is decorated with GAD-immunoreactive puncta. Scale bars, 0.1 $\mathrm{mm}$. 

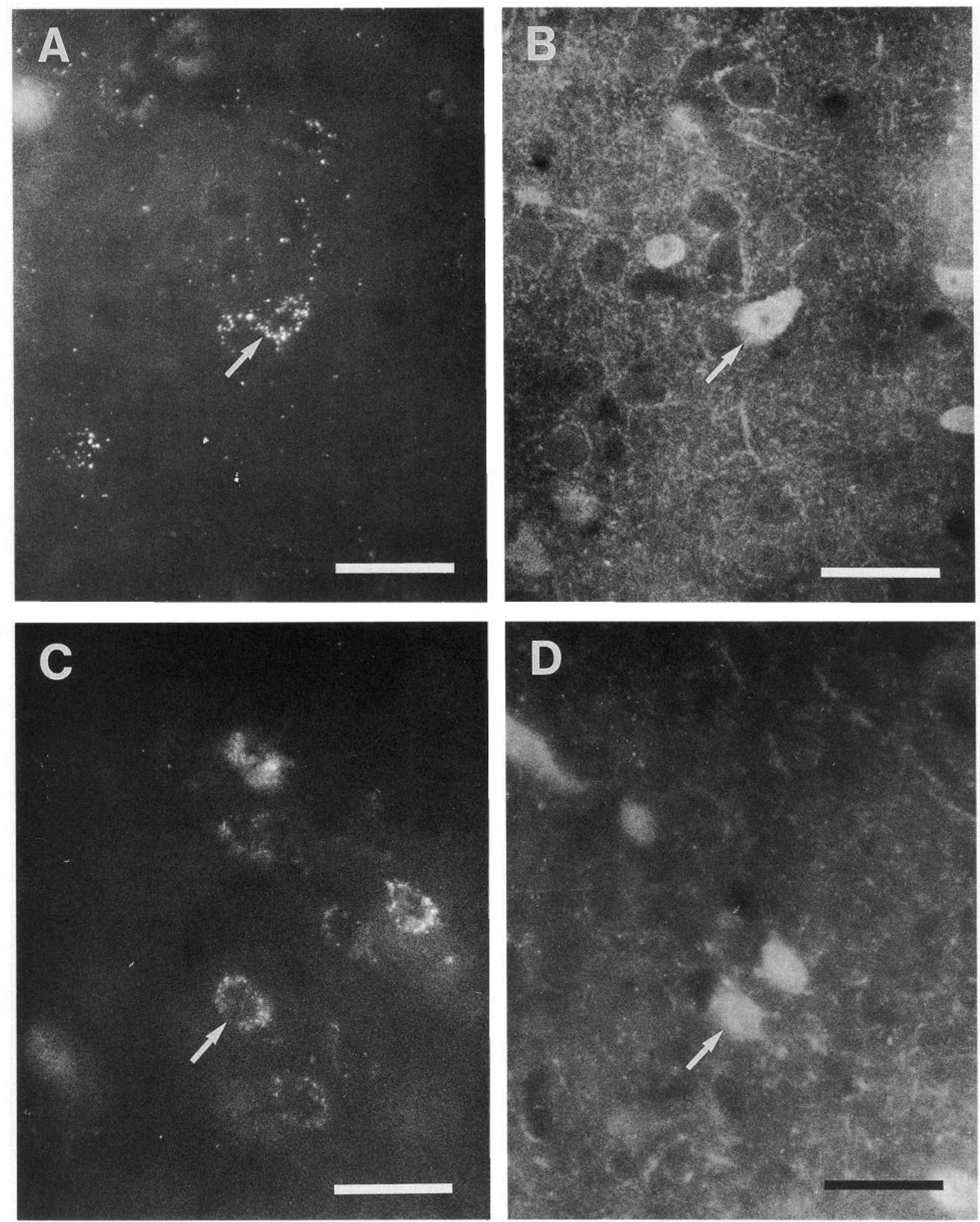

Figure 4. GABAergic projection neurons with long-ranging projections within area 17. A, Fluorescence photomicrograph of bead-labeled neuron (arrow) at layer $5 / 6$ border, $\sim 0.9 \mathrm{~mm}$ from the margin of the injection site in area 17. B, GAD immunofluorescence in section shown in $A$. Cell indicated by arrow expresses GAD immunoreactivity. The same cell is also labeled with beads (arrow in $A$ ). $C$, Bead-labeled cell (arrow) in superficial layer 6 of area 17, 0.8 mm from the margin of the injection site in area 17. D, Colocalization of GAD immunofluorescence in neuron shown in $C$ (arrow). Notice that although $A$ and $B$, and $C$ and $D$ are photographed in identical focal planes and beads are distributed throughout the cell bodies, the subcellular compartments labeled with beads and GAD are not in perfect register. Scale bars, $50 \mu \mathrm{m}$. 
the bottom of layers 5 and 6 . The distribution in upper layer $2 / 3$ and the middle of layers 5 and 6 was much tighter and labeled cells tended to be closer to the injection site. Higherpower pictures of this sublaminar labeling pattern are shown in Figures $1 C$ and 2.

GAD-immunostained, parasagittal sections revealed a large number of darkly labeled cells and puncta in all layers of primary visual cortex (Fig. $1 B, D$ ). In agreement with previous findings (Lin et al., 1986), GAD-labeled neurons were uniformly distributed throughout the visual cortex. Similar pictures were obtained with immunofluorescence (not shown). In all cases that allowed classification, GAD-immunoreactive cells had nonpyramidal morphologies and some resembled the "double bouquet" cells (see Figs. $8 B, C, 10 D$ ) described by Feldman and Peters (1978). The GAD staining pattern within area 17 was unaffected by local injections of beads, and despite the lesion caused by the injection pipette, GAD labeling in adjacent sections appeared normal (Fig. $1 C, D$ ). This point is reinforced in Figure 2, which shows GAD-immunoreactive neurons next to a bead injection site in the midst of fluorescently labeled cell bodies. It is also important to note that in this immunoperoxidase-stained section the laminar pattern of bead-labeled cells is indistinguishable from that observed in sections that were not immunostained (e.g., Fig. 1 $A$ ). This indicates that the immunoperoxidase staining does not noticeably reduce the number of detectable retrogradely labeled neurons. Examination at higher power of double-labeled sections revealed numerous beadlabeled neurons that were also immunoreactive for GAD. An example of such a double-labeled cell found in layer $3, \sim 0.4$ $\mathrm{mm}$ from the injection site, is shown in Figure $3, A$ and $B$, which both depict the same frame phctographed at the same focal plane under fluorescence and bright-field illumination, respectively. It is evident that GAD+/head-labeled cells (Fig. $3 A$, large arrow) contain slightly fewer beads than bead-only neurons (Fig. $3 A$, small arrow). This may pose a problem for detecting cells that express weak GAD staining. However, it is important to stress that the punctate appearance of bead-labeled neurons is distinctive even if labeling is relatively weak.

Interestingly, GAD-immunoreactive, bead-labeled cells were not only encountered near the injection site but were frequently located up to $1.2 \mathrm{~mm}$ from the injection. GAD-staining cells with such long-ranging projections were most commonly found along the layer $5 / 6$ border. Several examples of double-labeled layer $5 / 6$ cells are shown in Figure $3 C$. Similar to Figure $3 A$, the fluorescence signal in double-labeled cells is weaker than in bead-only neurons. However, because of the punctate appearance of beads, in most cases it was easy to identify doublelabeled cells unequivocally. In spite of this, we felt compelled to confirm the existence of long-range GABAergic connections by visualizing GAD with immunofluorescence. Examples of double-labeled layer $5 / 6$ cells that were found between 0.8 and $1.0 \mathrm{~mm}$ from the edge of the injection site are shown in Figure 4.

It is important to point out that due to the nonuniform subcellular distribution of beads, the fluorescence and bright-field images of double-labeled cells are often not in perfect register. This is true even in cases in which double labeling is assessed in a single picture, taken under simultaneous fluorescence and bright-field illumination (Fig. 3C). Although in all other cases double-labeled cells are illustrated by pairs of pictures, they were always taken in the same focal plane. For independent verification, it is instructive to look at the immunoperoxidase-stained material and to compare GAD-labeled profiles under both types of illuminations (e.g., Fig. $3 A, B$ ). Although under fluorescence
A

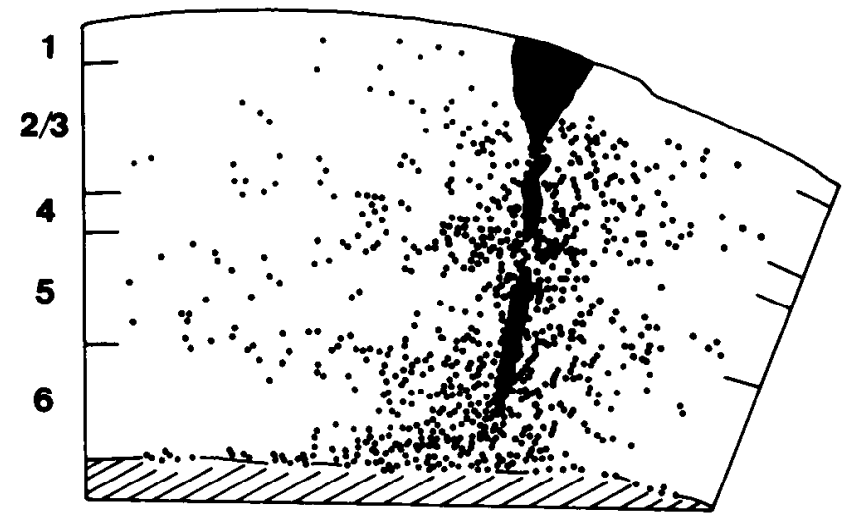

B

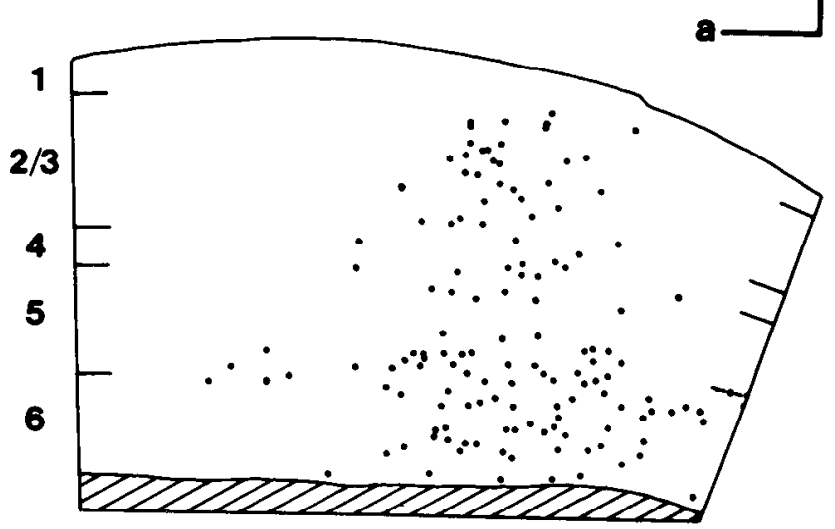

Figure 5. A, Plot of distribution of retrogradely bead-labeled cells (dots) within area 17 . Single parasagittal section. Injection site is highly elongated and extends throughout layers 1-6. $B$, Reconstruction of distribution of GAD +/bead double-labeled neurons. The dots represent double-labeled cells from three parallel sections: section shown in $A$, and two sections $0.2 \mathrm{~mm}$ medial and lateral to it. GABAergic cells at the layer $5 / 6$ border have the most wide-ranging axon collaterals that reach up to $1.2 \mathrm{~mm}$ in the tangential plane. $a$, anterior; $d$, dorsal. Scale bar, $0.5 \mathrm{~mm}$.

optics nonfluorescent profiles, if visible (e.g., see Fig. 7B,C), appear out of focus, it is easy to pick out the same GAD-positive puncta in both images. This strongly indicates that both pictures were taken in very similar focal planes.

To obtain a more complete view of the arrangement of GABAergic connections within area 17 , the distribution of doublelabeled cells was plotted in immunoperoxidase-stained sections. Figure $5 \mathrm{~A}$ shows the pattern of bead-labeled cells in a parasagittal section following an injection into area 17 involving layers 1-6. Figure $5 B$ shows the distribution of bead-labeled neurons that also showed GAD immunoreactivity. This plot was obtained by pooling double-labeled cells from three parallel sections: the section shown in Figure $5 A$ and two sections $0.2 \mathrm{~mm}$ medial and lateral to it. While the majority of double-labeled cells were confined within $0.3-0.4 \mathrm{~mm}$ of the injection site, the distribution of cells at the layer $5 / 6$ border was more widespread and cells were found up to $1.2 \mathrm{~mm}$ from the injection site. The spread in the coronal plane was less extreme. The overall dis- 
Figure 6. A, Dark-field photomicrograph of unstained horizontal section through flattened cerebral hemisphere of rat. Light areas represent regions of dense myelination. Area 17 resembles a parabola-shaped region located in medial occipital cortex. Arrow indicates bead injection site (bright spot) in area 17. Anterior is to the top; lateral is to the left. $B-D$ are the same orientation as $A . B$, Dark-field photomicrograph of horizontal section showing myeloarchitecture of rat cerebral cortex. Arrow indicates bead injection site into the cytoarchitectonic subdivision, 18a. C, Fluorescence photomicrograph of bisbenzimide-labeled callosal projections in flattened cerebral cortex of same rat as shown in A. Arrow indicates bead injection into area 17. The callosal-free zones within the cytoarchitectonic subdivision $18 \mathrm{a}$, lateral to area 17 (myeloarchitectonic borders indicated by broken line), contain area $A L$ (anterolateral), area $L M$ (lateromedial), and $P X$ (posterior extrastriate complex). D, Fluorescence photomicrograph of bisbenzimide-labeled, callosal projection in a flattened cerebral cortex of same rat as shown in $B$. Bead injection ( $a r$ row) is identified in $P X$. Myeloarchitectonic borders of area 17 are indicated by broken line.
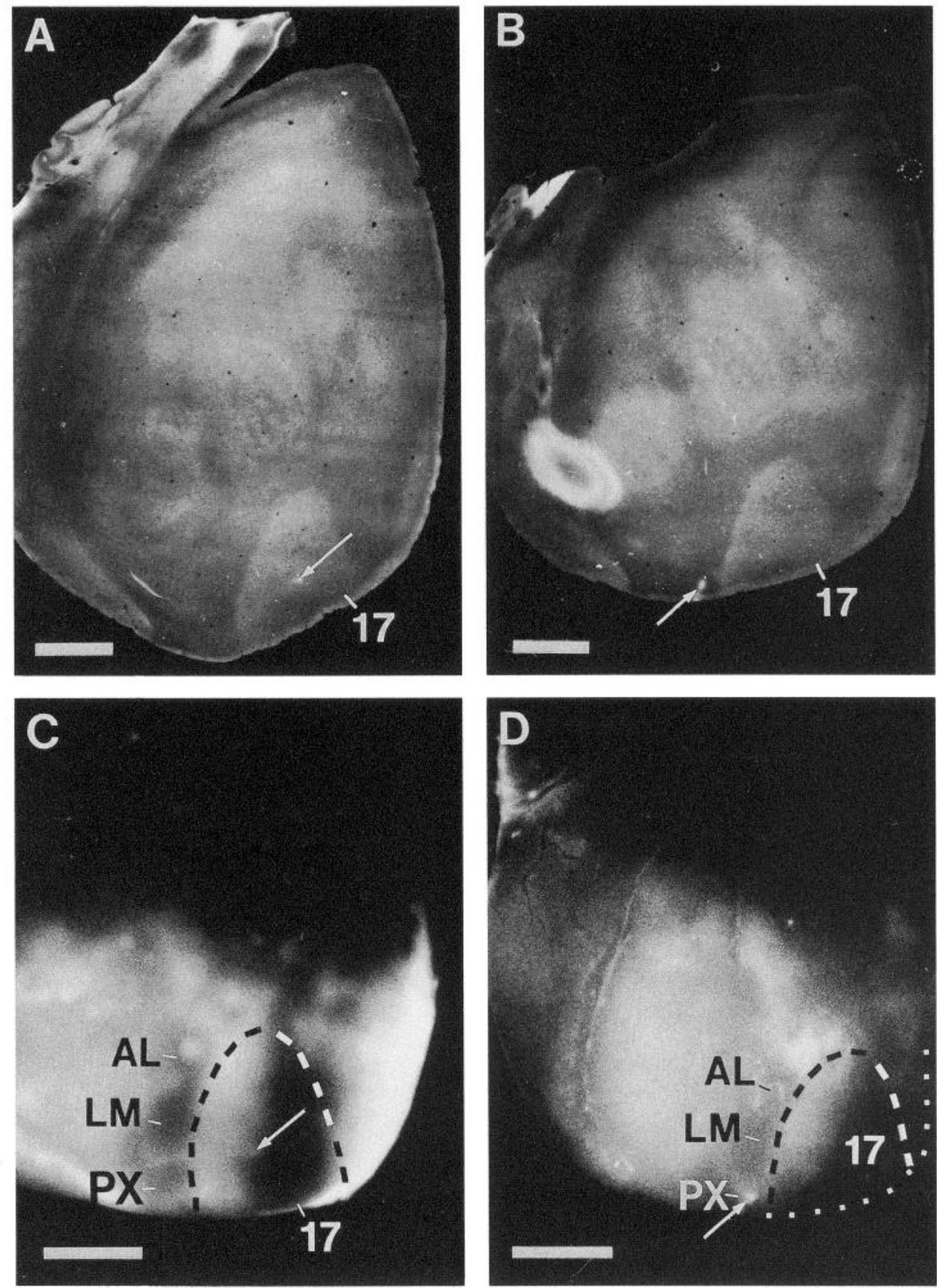

tribution of cells was elliptical, with the long axis parallel to the parasagittal plane and the short axis in the coronal plane (Burkhalter and Charles, 1990). Remarkably, other layers and sublaminae that contain similar long-range projections, that is, lower layer $2 / 3$, upper layer 5 , and deep layer 6 , show much more restricted distributions ( $\sim 0.4 \mathrm{~mm}$ wide) of double-labeled cells.

\section{Inhibitory connections between visual areas}

To examine whether connections between different cortical areas express GABAergic properties, fluorescent beads were injected into area 17 and the cytoarchitectonic subdivision 18a. Based on the distinctive myeloarchitecture of primary visual cortex, which was revealed as a whitish parabola-shaped area in unstained sections viewed under dark-field illumination (Fig. $6 A, B$ ), six injection sites were identified in area 17 (Fig. $6 A$, arrow) and six additional injections were recovered in area $18 \mathrm{a}$ (Fig. 6B, arrow) near the lateral border of area 17. Because the cytoarchitectonic area $18 \mathrm{a}$ is composed of several distinct visual areas, it was necessary to trace in each case the interhemispheric connections for delineating areal boundaries (Olavarria and Montero, 1984; Thomas and Espinoza, 1987). The callosal projection patterns for the cases illustrated in Figure $6, A$ and $B$, are shown in $C$ and $D$, respectively. It is evident from the comparison of $A$ and $C$ that the injection shown in Figure $6 A$ was confined to the callosal-free region of area 17 (Fig. 6C). By contrast, the injection shown in Figure $6 B$ lies lateral to the callosally connected strip that demarcates the $17 / 18$ a border and is located at the posterior tip of the lateromedial area (LM), immediately in front of the posterior complex (PX; Fig. 6D). In five cases, extrastriate injections were recovered in LM. A single case showed an injection into PX (not shown).

Area 17 injections produced a stereotypical distribution of bead-labeled neurons both within area 17 and in different extrastriate areas that border striate cortex laterally and medially 

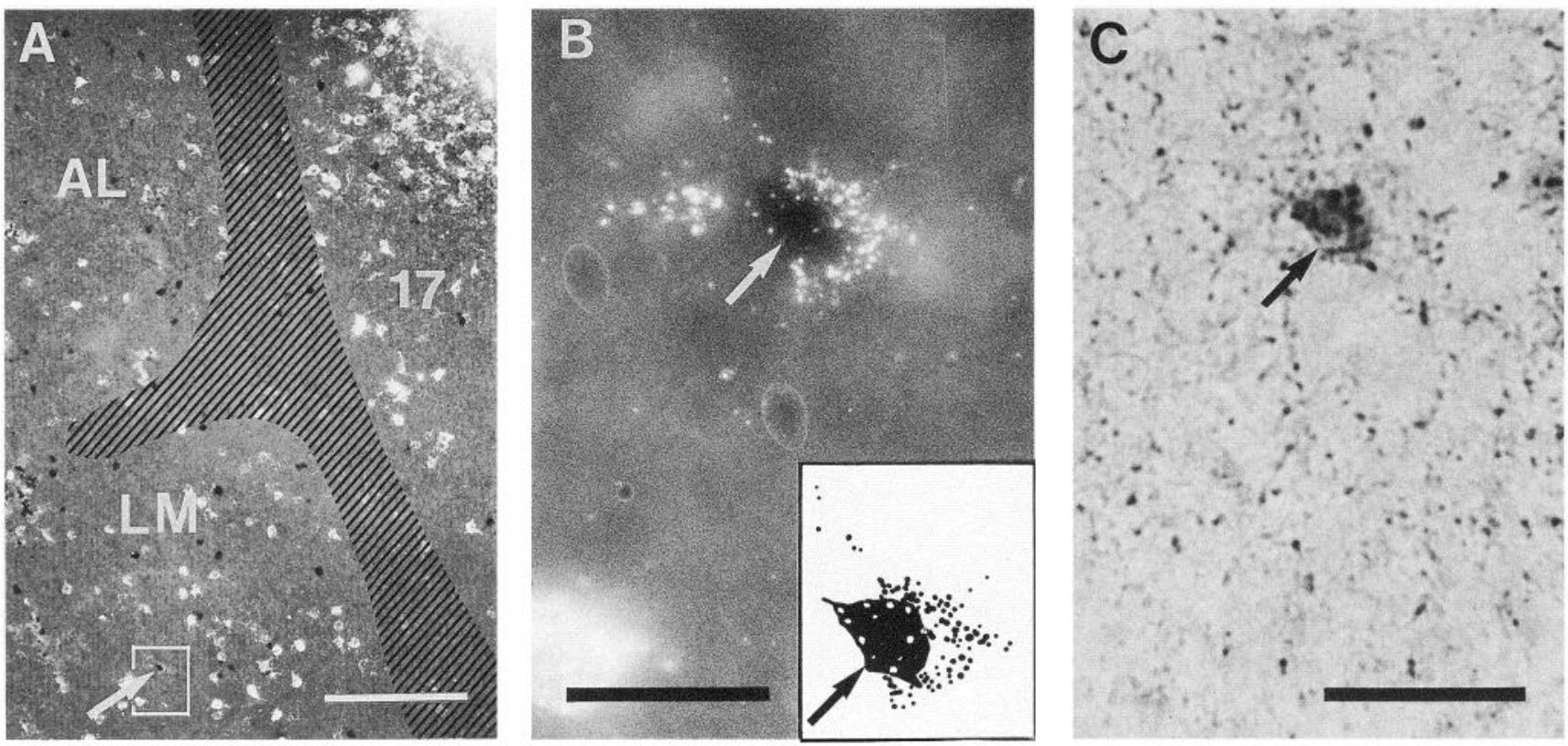

Figure 7. GABAergic projections from extrastriate visual cortex to area 17. A, Fluorescence photomicrograph of horizontal section through rat visual cortex. Extrastriate projection neurons in areas $L M$ (lateromedial area) and $A L$ (anterolateral area) are retrogradely labeled with beads (bright cell bodies) after injection into area 17 (bright spot in upper right corner). GAD immunoperoxidase-stained cells (black dots) are seen in background. Hatched area indicates the callosally connected zone, marked after bisbenzimide injections into opposite hemisphere. Arrow points to a GAD + / bead-labeled neuron in area LM. Anterior is toward the top; lateral is to the left. $B$, High-power fluorescence photomicrograph of boxed area shown in A. Arrow indicates GAD-stained projection neuron (dark profile) in area LM. Bright dots in dark cell body represent retrogradely transported beads. Notice that double-labeled cell lies on top of an densely bead-labeled pyramidal cell. Although the fluorescence signal of the double-labeled cell is quenched by the reaction product, the dark profile of the cell body is outlined by bright bead labeling (see inset). This indicates that double labeling is not an artifact and that bead labeling of GAD-positive cell does not represent fluorescence signal from cell below. Because the section was not cleared and was mounted in buffer, GAD-labeled puncta in background (see $C$ ) are not resolved under epifluorescence illumination. $C$, Bright-field photomicrograph of GAR-labeled cell (arrow) depicted in $B$. Scale bars: $A, 0.25 \mathrm{~mm} ; B$ and $C, 50 \mu \mathrm{m}$.

(see Fig. 9A). A fluorescence photomicrograph of bead-labeled cells in LM and anterolateral (AL) areas is shown in Figure $7 A$ (injection site in area 17 shown in Fig. $6 A$ ). Much to our surprise, a small number of the bead-labeled cells in extrastriate cortex were also GAD immunoreactive. The example shown in Figure 7 was found in an immunoperoxidase-stained horizontal section. It lies in the area LM, $1.2 \mathrm{~mm}$ posterolateral to the margin of the injection site (Fig. $7 A$ ). At higher power (Fig. $7 B, C$ ), the cell can be recognized as a darkly GAD-stained neuron that contains $\sim 10$ fluorescent beads. The cell lies on top of another neuron that is labeled with beads only, and partially covers it. Although both cell types lie in very similar focal planes, it is nevertheless easy to distinguish the two by the shape outlined with beads: the double-labeled cell is oval with the long axis at 10 o'clock, the bead-only cell is triangular with the apex pointing to 11 o'clock (Fig. $7 B$, inset). This clearly shows that the GADpositive neuron is indeed double labeled, and that the bead labeling is not an artifact of seeing attenuated fluorescence through the dark soma from the cell underneath. Two additional examples of fluorescently stained GABAergic feedback-projecting neurons from LM are shown in Figure 8. The cell in Figure 8, $A$ and $B$, was found in layer $2 / 3$, whereas the neuron depicted in $C$ and $D$ derives from layer 5 . Both cells have a bipolar morphology and are clearly nonpyramidal.

Although the proportion of double-labeled cells was small compared to bead-labeled cells $(\sim 0.5 \%)$, one or two examples were consistently found in each section. Figure $9 B$ represents a reconstruction of a single case in which double-labeled cells from six sections from layers 2/3-6 were pooled. It shows that GABAergic intracortical projections arise not only from LM, but also from AL, PX, the rostrolateral area (RL), the medial extrastriate complex (MX), and the cortex lateral to area LM. All of these projections originate from GAD-labeled cells that are distributed uniformly throughout all layers. Because it was technically difficult to examine layer 1 in horizontal sections, it remains unresolved whether it contributes to interareal GABAergic connections.

Injections into the cytoarchitectonic subdivision $18 \mathrm{a}$ revealed bead-labeled neurons in area 17 and in many extrastriate areas of the occipital and temporal lobes, including entorhinal cortex and the retrosplenial cortex. After an injection into LM, GADstained sections revealed GAD +/bead double-labeled neurons in all layers of area 17. An example of a double-labeled layer $2 / 3$ cell next to GAD-only and bead-only labeled neurons is shown in Figure 10. In reference to Figure $10, A$ and $B$, it is important to point out again that both panels derive from very similar focal planes. Because Figure $10 \mathrm{~A}$ was taken under epifluorescence illumination, GAD-labeled profiles appear blurred and the image seems to represent a different focal plane than that shown in Figure $10 \mathrm{~B}$. Nevertheless, to control for falsepositive identifications of double-labeled cells, we used immunofluorescence. Figure $10, C$ and $D$, shows GAD-labeled forward-projecting neurons in area 17 that terminate in area PX of extrastriate cortex.

Similar to feedback-projecting cells, the number of GABAergic forward-projecting neurons is small and constitutes less than $0.5 \%$ of the striate cortical projection to LM. GABAergic corticocortical connections were also found within extrastriate cortex. The result of an injection into the PX is shown in Figure 11. PX receives input from area $17, \mathrm{LM}, \mathrm{AL}, \mathrm{MX}$, the temporal 

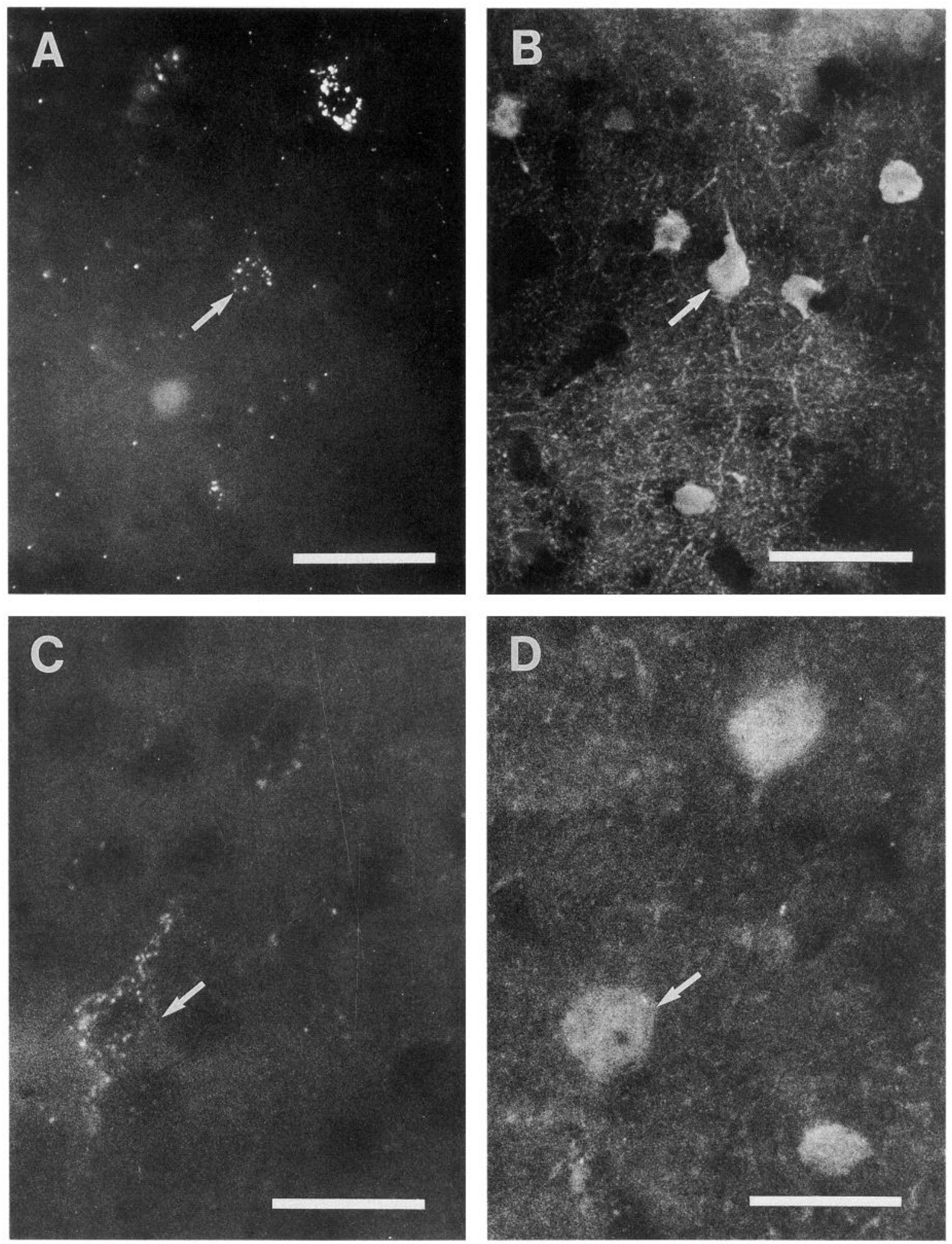

Figure 8. GABAergic neurons in extrastriate area LM that project back to area 17. A, Bead-labeled neuron (arrow) in layer $2 / 3$ of area LM after tracer injection into area 17. $B$, GAD immunofluorescence colocalized in bead-labeled cell depicted in $A$. $C$, Bead-labeled neuron (arrow) in layer 5 of area LM after tracer injection into area 17. $D$, GAD immunofluorescence colocalized in bead-labeled cell shown in $C$. Scale bars: $A$ and $B$, 50 $\mu \mathrm{m} ; C$ and $D, 25 \mu \mathrm{m}$.

cortex, the entorhinal cortex, and the retrosplenial area (Fig. $11 \mathrm{~A}$ ). The distribution of double-labeled cells (Fig. $11 B$ ) shows that a small fraction of the input from most of these areas originates from GAD-immunoreactive neurons.

\section{Discussion}

Combining retrograde tracing of connections within rat primary visual cortex with immunocytochemistry of GAD, the rate- 

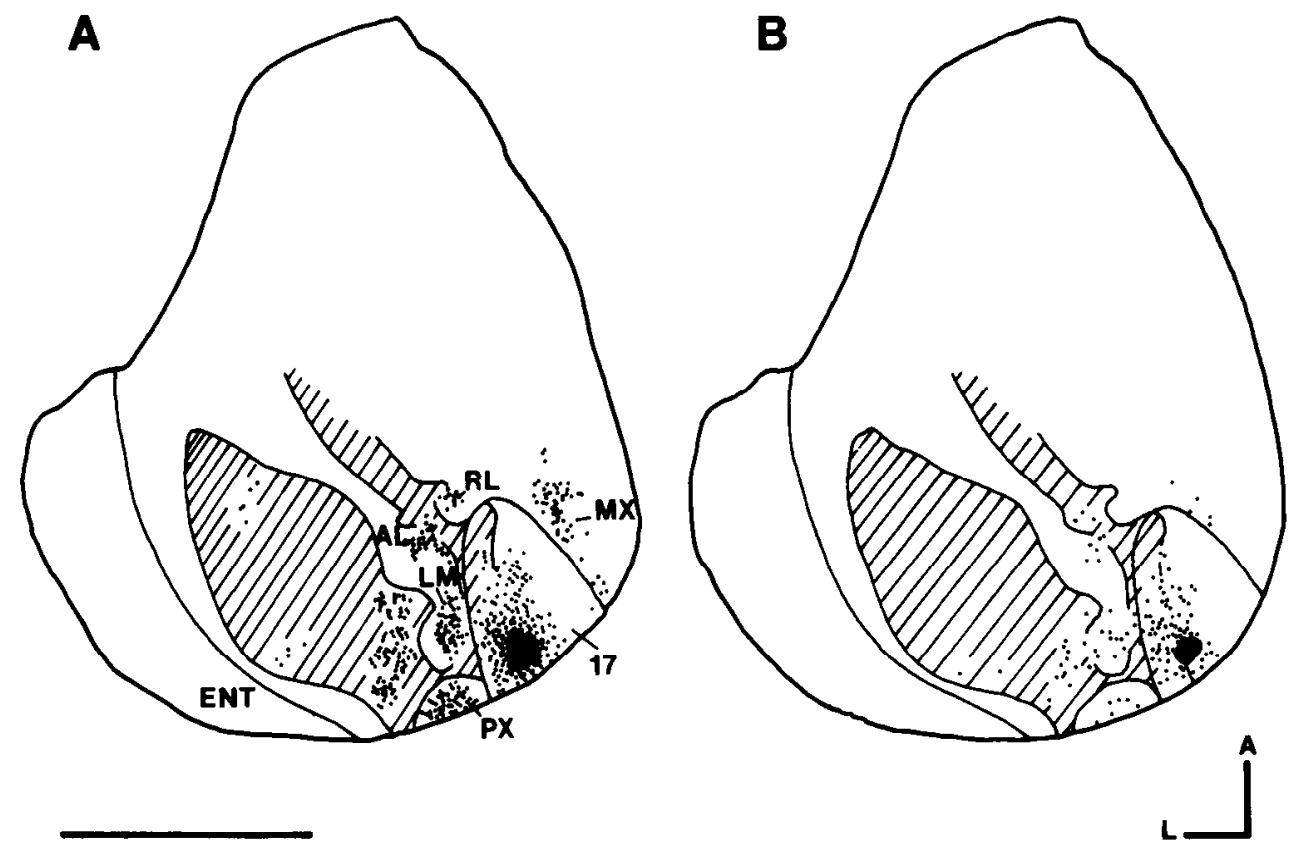

Figure 9. $A$, Distribution of bead-labeled neurons (dots) in single horizontal section through rat cerebral cortex retrogradely labeled after injection into area 17. Bead-labeled neurons are found in area 17 , areas $L M, A L, R L$ (rostrolateral), $P X$, and $M X$ (medial complex), and in unidentified regions of temporal lobe. Hatched areas represent callosally connected regions determined from bisbenzimide labeling pattern after injection of the opposite hemisphere. $B$, Distribution of GAD +/bead cells (dots). Same case as $A$. Data are pooled from six sections through depth of cerebral cortex. A small number of GAD +/bead neurons are seen in all areas that contain bead-labeled cells. Notice that the distributions of bead-labeled cells in $A$ and of GAD $+/$ bead cells $B$ are not perfectly overlapping. This is because $A$ represents a single section, whereas $B$ is a composite from six sections. $E N T$, entorhinal cortex. $A$, anterior; $L$, lateral. Scale bar, $5 \mathrm{~mm}$. limiting synthetic enzyme for GABA, we have obtained two main results. First, we have identified a subpopulation of GABAergic neurons lying at the border of layers 5 and 6 that make long-range connections within primary visual cortex. Second, we found a small but significant number of GABAergic neurons that make forward and feedback projections between different cortical areas. Because GABA is the main inhibitory transmitter in the cortex, these results support the notion that within primary visual cortex direct inhibitory interactions occur between different points of the visuotopic map. In addition, monosynaptic inhibitory interactions may also play a role in reciprocal circuits between different cortical areas.

The current understanding of the organization of intracortical GABAergic connections derives principally from the combination of HRP-filled neurons with GABA immunocytochemistry (Martin et al., 1983; Somogyi and Soltez, 1986; Kisvarday et al., 1987) and retrograde tracing with ${ }^{3} \mathrm{H}$-GABA (Somogyi et al., 1981, 1983b; DeFelipe and Jones, 1985). These investigations in cat and monkey visual and somatosensory cortex have stressed that GABAergic neurons make interlaminar connections, and that they may provide for inhibitory interactions within individual cortical columns that represent a single point in space. However, although Somogyi et al. (1981) have focused on intracolumnar connections, they found ${ }^{3} \mathrm{H}-\mathrm{GABA}-$ labeled cells in layer 6 that spread far beyond individual columns. This is similar to what we have observed in layers 5 and 6 of rat area 17. Thus, the horizontal range of these GABAergic connections strongly suggests that deep layers may provide for direct inhibitory interactions between distant points of the topographic map. Most interestingly, these interactions seem to arise exclusively from cells at the layer $5 / 6$ border, whereas cells in deep layer 6 , superficial layer 5 , and deep layer $2 / 3$, which all contribute to long-range connections within area 17 (Burkhalter, 1989; Burkhalter and Charles, 1990; present results), appear not to participate in direct long-range inhibitory interactions.

\section{Long-range GABAergic connections within area 17}

Long-range inhibitory interactions in visual cortex are polysynaptic and are thought to be mediated indirectly by excitatory contacts on local inhibitory neurons (Ts'o et al., 1986; Gabott et al., 1987; McGuire et al., 1991). Although there are no reports of monosynaptic long-range inhibitory interactions (but see Asanuma and Rosen, 1973), numerous studies suggest the presence of long-ranging inhibitory connections within visual cortex: (1) GABAergic basket cells make extensive axonal projections in cat areas 17 and 18 (Martin et al., 1983; Somogyi et al., 1984; Kisvarday et al., 1987; Eysel and Kisvarday, 1991), (2) GABAimmunoreactive cells in cat area 18 have long-ranging local axon collaterals (Matsubara et al., 1987; Matsubara, 1988), and (3) retrograde tracing of local GABAergic projection neurons in area 18 with ${ }^{3} \mathrm{H}$-nipecotic acid labels neurons that are $>1 \mathrm{~mm}$ from the injection site (Crook et al., 1992). From Golgi studies (Werner et al., 1979, 1985) and intracellular HRP injections (Berman and Martin, 1990) of basket cells in rat area 17, it seems reasonable to assume that similar connections also exist in rat primary visual cortex. Although little is known about the axonal arbors of basket cells in rodents, similar cells in cat striate cortex clearly contribute to local long-range projections (Kisvarday et al., 1987). In cats, basket cells reside in layer $2 / 3$ and 5. The laminar distribution in rat visual cortex is not known, but it is intriguing that the examples shown by Werner et al. (1979) and Berman and Martin (1990) are in lower layers and thus lie in the lamina from which GABA-immunoreactive neurons project wide-ranging axon collaterals.

Using nonselective tracers, we have shown previously that the layer $5 / 6$ border contains cells with long-ranging axon collaterals that extend within layers 5 and 6 , but also project to layers 2/3 and 4 (Burkhalter, 1989; Burkhalter and Charles, 1990). More recently, we have found that many neurons in this layer can be labeled by retrograde transport of ${ }^{3} \mathrm{H}-\mathrm{D}$-aspartate after injections into layers 2/3-6 of area 17 (Johnson and Burkhalter, 1992). Thus, cells at the layer $5 / 6$ border contribute to excitatory and inhibitory long-range projections. Based on the morphology of basket cells, it appears that both cell types have different local projection targets: long-ranging fibers of GABAergic neurons may be confined to the layers 5 and 6 , while excitatory long-range projections include targets in middle and upper layers. The most likely targets of inhibitory projections 

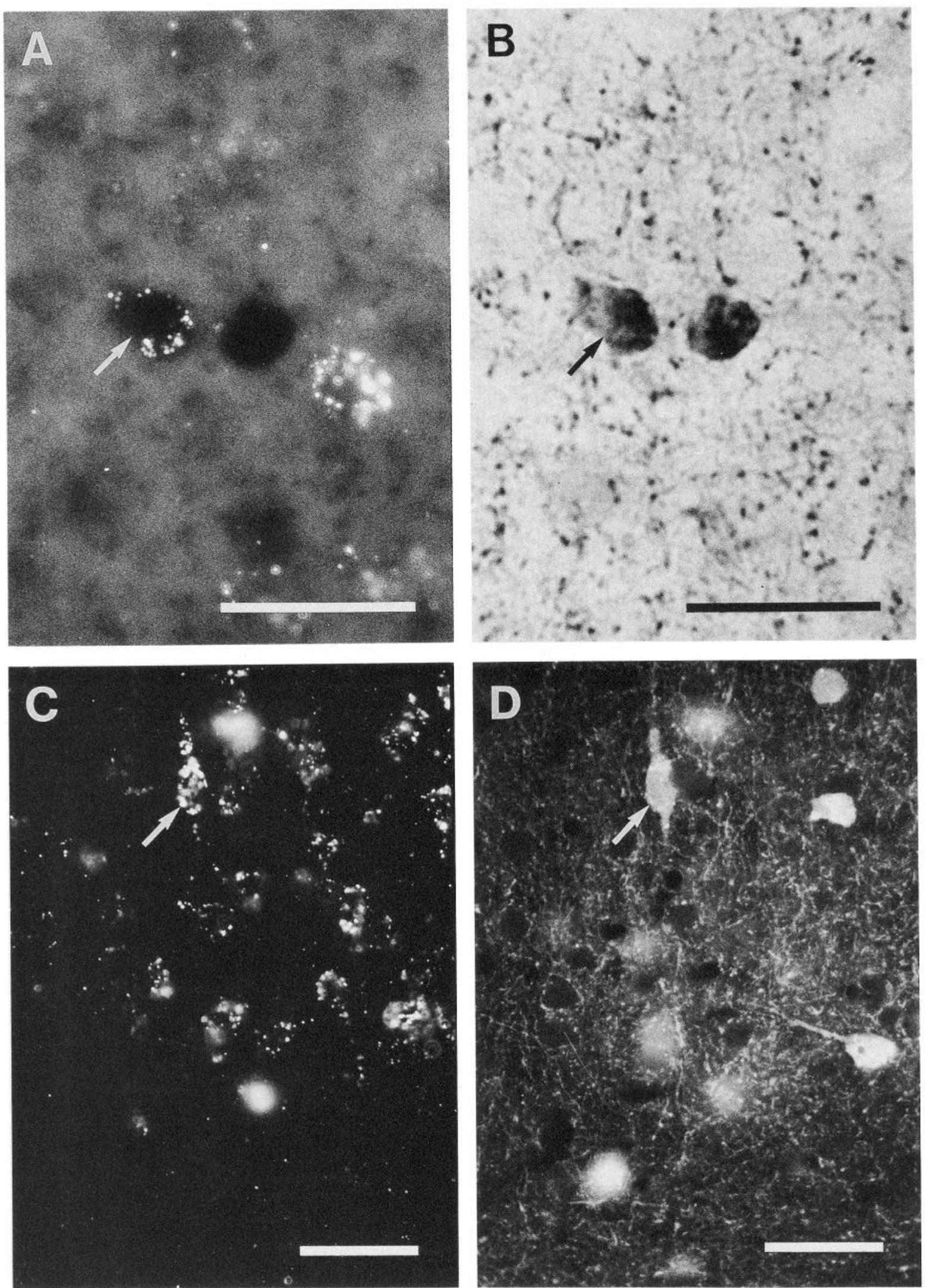

Figure 10. GABAergic neurons in area 17 that project to areas LM and PX. A, Fluorescence photomicrograph showing bead-labeled neurons in layer $2 / 3$ of area 17 retrogradely labeled after injection into area LM. Dark profiles in background indicate GAD-positive cell bodies and puncta. Cell indicated by arrow is GAD+/bead double labeled. $B$, Bright-field photomicrograph of picture shown in $A$. Immunoperoxidase-labeled GADpositive cell marked with arrow represents the bead-labeled cell arrow in $A$. $C$, Bead-labeled neurons in layer $2 / 3$ of area 17 , after tracer injection into area PX. Bipolar cell indicated by arrow expresses GAD immunoreactivity $(D)$. $D$, GAD immunofluorescence of neurons in area 17 . Cell marked with arrow represents bead-labeled neuron depicted in $C$. Scale bars, $50 \mu \mathrm{m}$. 


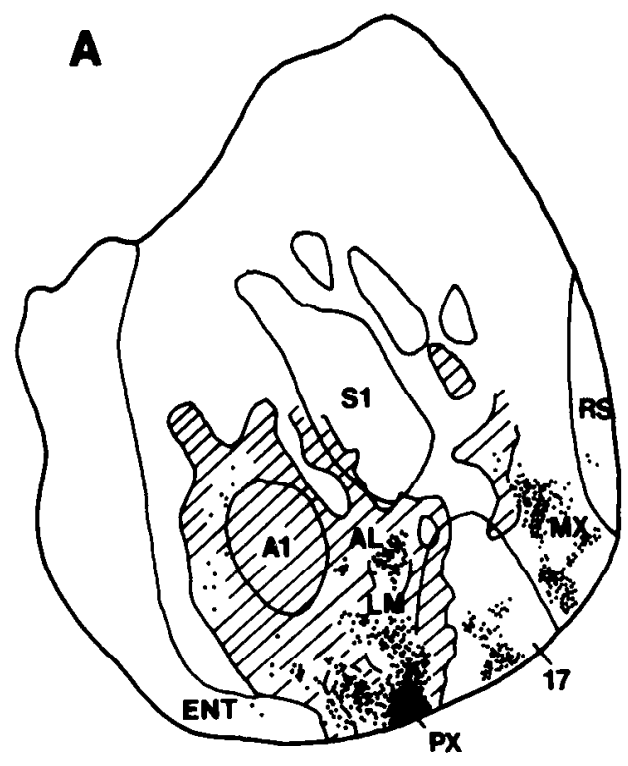

within layer 5 are colliculus-projecting and corticocortically projecting cells (Burkhalter and Charles, 1990). Indeed, powerful inhibitory postsynaptic potentials were recorded in cells that are morphologically similar to intracortically projecting neurons (Hallman et al., 1988; Chagnac-Amitai et al., 1990). Although similar responses were also recorded from cells that are morphologically similar to corticotectal neurons, the inhibition was much less potent (Schofield et al., 1987; Chagnac-Amitai et al., 1990). If one assumes that this inhibition arises at least in part from cells at the layer $5 / 6$ border, this finding suggests that the inhibitory input may derive from two different types of inhibitory neurons: chandelier cells with short axons (Peters et al., 1982) whose axoaxonic contacts may exert the powerful inhibition on corticocortically projecting neurons (Freund et al., 1983; DeFelipe et al., 1985), and basket cells with long-ranging axons whose axosomatic contacts may provide for the more subtle inhibition of corticotectal neurons (Gabott et al., 1988). In cat visual cortex, basket cells in layer 4 receive direct thalamocortical input (Freund et al., 1985). This may be a general feature of thalamocortical organization. Thus, in rat visual cortex in which geniculocortical input is sent to layer 4 and the layer $5 / 6$ border (A. Burkhalter, unpublished observations), thalamocortical fibers may terminate on basket cells in deep layer 5. This organization would allow direct thalamocortical access to a wide-ranging intracortical system that may serve to suppress corticotectal neurons at distant points of the topographic map. Although this could also be achieved by a circuit in which geniculate inputs to distant corticotectal cells are mediated via a chain of long-ranging intracortical collaterals of pyramidal cells and short inhibitory neurons, transmission would be (1) slower because of additional synaptic delays and (2) distorted by the nonlinear discharge properties of pyramidal cells, which unlike nonpyramidal cells show marked spike frequency adaptation (McCormick et al., 1985).

It has been suggested that long-range inhibitory intracortical interactions are important for the generation of direction selectivity (Eysel et al., 1988) or for providing for "cross orientation inhibition," which may underlie orientation tuning in cat visual cortex (Matsubara et al., 1987; Crook and Eysel, 1992). We have argued that in rat visual cortex long-ranging inhibitory connections may preferentially terminate on corticotectal neurons. Because these cells are not directionally selective (Lemmon and Pearlman, 1981), basket cell input must serve a different function. Although a role in "cross orientation inhibition" cannot be ruled out, this seems a remote possibility, as there is no evidence for orientation columns in rodent visual cortex (Dräger, 1975; Tiao and Blakemore, 1976). Thus, it is most likely that long-range GABAergic neurons play a rolc in the lateral inhibition of corticotectal neurons. This mechanism may facilitate the guidance of quick head movements to small visual targets.

\section{Long-range connections between different areas}

We have identified a small population of neurons that provide long-distance connections between different visual areas. These cells arise from all layers, with the possible exception of layer 1. They make forward projections from area 17 to at least two extrastriate areas: the LM and the PX. GABAergic feedback projections originate from multiple representations in the cytoarchitectonic subdivision 18 a (i.e., areas LM, AL, PX, RL) and $18 \mathrm{~b}$ (i.e., MX). In addition, there are long-distance inhibitory connections between different extrastriate areas.

The presence of long-distance GABAergic connections that link different cortical areas is a matter of contention. In a direct test of the question, Voigt et al. (1988) have looked at the callosal connection but they failed to find GABAergic projection neurons. Typically, GABAergic neurons have nonpyramidal morphologies, do not have dendritic spines, and their axons form symmetric synaptic contacts. Interestingly, cells with similar attributes were found to project across the corpus callosum (Buhl and Singer, 1989; Hughes and Peters, 1989; Peters et al., 1990). Thus, it is possible that some GABAergic neurons remained undetected in the immunological study of Voigt et al. (1988). However, based on reports that $\sim 15 \%$ of cortical neurons are 
nonpyramidal (Peters and Kara, 1985) and that of these 10$32 \%$ project across the corpus callosum (Peters et al., 1990), we estimate from our results that there must be 3-10 times more transcallosally projecting nonpyramidal cells than what we have estimated for GABAergic connections between areas of the same hemisphere. This suggests that most of the interhemispheric, and possibly also most of the interareal projections made by nonpyramidal neurons are non-GABAergic. Nevertheless, our results show that some of these cells express GABAergic properties and may provide for inhibitory interareal interactions (Miller and Vogt, 1984).

There are numerous examples of long-range inhibitory interactions in the cortex. Perhaps the best-documented cases are those that are mediated across the corpus callosum (Swadlow, 1974; Innocenti, 1980; Diao et al., 1983). Similar interactions take place between primary and secondary visual cortex. Sandell and Schiller (1982) have shown that cooling of V2 renders some striate cortical neurons more responsive to visual stimulation. This may be the result of disinhibition. The functional changes, however, provide little insight into the underlying circuitry. Previously, these effects were thought to be due to the elimination of excitatory feedback to inhibitory interneurons in V1 (but see Vogt and Gorman, 1982). The results of this study indicate that interactions between different areas can also be controlled by monosynaptic inhibitory circuits.

\section{References}

Alloway KD, Rosenthal P, Burton H (1989) Quantitative measurements of receptive field changes during antagonism of GABAergic transmission in primary somatosensory cortex of cats. Exp Brain Res $78: 514-532$.

Asanuma H, Rosen I (1973) Spread of mono- and poly-synaptic connections within cat's motor cortex. Exp Brain Res 16:507-520.

Berman NJ, Martin KAC (1990) Cortical circuits reviewed. Trends Neurosci 13:445-446.

Buhl EH, Singer W (1989) The callosal projection in cat visual cortex as revealed by a combination of retrograde tracing and intracellular injection. Exp Brain Res 75:470-476.

Burkhalter A (1989) Intrinsic connections of rat primary visual cortex: laminar organization of axonal projections. J Comp Neurol 279:171186.

Burkhalter A, Charles V (1990) Organization of local axon collaterals of efferent projection neurons in rat visual cortex. J Comp Neurol 302:920-934.

Chagnac-Amitai Y, Luhmann HJ, Prince DA (1990) Burst generating and regular spiking layer 5 pyramidal neurons of rat neocortex have different morphological features. J Comp Neurol 296:596-613.

Chang Y-C, Gottlieb DI (1988) Characterization of the proteins purified with monoclonal antibodies to glutamic acid decarboxylase. $\mathrm{J}$ Neurosci 8:2123-2130.

Crook JM, Kisvarday ZF, Eysel UT (1992) Contribution of lateral inhibition to orientation and direction selectivity in cat visual cortex (area 18): GABA-inactivation combined with injections of $\left[{ }^{3} \mathrm{H}\right]-n i-$ pecotic acid. In: Rhythmogenesis in neurons and networks (Elsner $\mathrm{N}$, Richter D, eds). Stuttgart: Thieme.

DeFelipe J, Jones EG (1985) Vertical organization of gamma-aminobutyric acid-accumulating intrinsic neuronal systems in monkey cerebral cortex. J Neurosci 5:3246-3260.

DeFelipe J, Hendry SHC, Jones EG, Schmechel D (1985) Variability in the terminations of GABAergic chandelier cell axons on initial segments of pyramidal cell axons in the monkey sensory-motor cortex. J Comp Neurol 231:364-384.

Diao Y-C, Wang Y-K, Pu M-L (1983) Binocular responses of cortical cells and the callosal projection in the albino rat. Exp Brain Res 49: $410-418$.

Dräger UC (1975) Receptive fields of single cells and topography in mouse visual cortex. J Comp Neurol 160:269-290.

Dykes RW, Landry P, Metherate R, Hicks TP (1984) Functional role of GABA in the cat primary somatosensory cortex: shaping receptive fields of cortical neurons. J Neurophysiol 52:1066-1093.

Eysel UT, Kisvarday ZF (1991) Specificity of lateral inhibitory connections in cat visual cortex. Soc Neurosci Abstr 17:116.

Eysel UT, Muche T, Wörgötter F (1988) Lateral interactions at direction-selective striate neurones in the cat demonstrated by local cortical inactivation. J Physiol (Lond) 399:657-675.

Feldman ML, Peters A (1978) The forms of non-pyramidal neurons in the visual cortex of the rat. J Comp Neurol 179:761-794.

Freund TF, Martin KAC, Smith AD, Somogyi P (1983) Glutamate decarboxylase-immunoreactive terminals of Golgi-impregnated axoaxonic cells and of presumed basket cells in synaptic contact with pyramidal neurons of the cat's visual cortex. J Comp Neurol 221: 263-278.

Freund TF, Martin KAC, Somogyi P, Whitteridge D (1985) Innervation of cat visual areas 17 and 18 by physiologically identified $X$ and $Y$-type thalamic afferents. II. Identification of postsynaptic targets by GABA immunohistochemistry and Golgi impregnation. J Comp Neurol 242:275-291.

Gabbott PLA, Somogyi P, Stewart MG, Hamori J (1986) Gaba-immunoreactive neurons in the dorsal lateral geniculate nucleus of the rat: characterization by combined Golgi-impregnation and immunocytochemistry. Exp Brain Res 61:311-322.

Gabbott PLA, Martin KAC, Whitteridge D (1987) Connections between pyramidal neurons in layer 5 of cat visual cortex (area 17). $\mathrm{J}$ Comp Neurol 259:364-381.

Gabbott PLA, Martin KAC, Whitteridge D (1988) Evidence for the connections between a clutch cell and a corticotectal neuron in area 17 of the cat visual cortex. Proc R Soc Lond [Biol] 233:385-391.

Hallman EL, Schofield BR, Lin C-S (1988) Dendritic morphology and axon collaterals of corticotectal, corticopontine, and callosal neurons in layer 5 of primary visual cortex of the hooded rat. J Comp Neurol 272:149-160.

Hata Y, Tsumoto T, Sato H, Hagihara K, Tamura H (1988) Inhibition contributes to orientation selectivity in visual cortex of cat. Nature 280:120-125.

Hendry SHC, Jones EG, DeFelipe J, Schmechel D, Brandon C, Emson PC (1984) Neuropeptide-containing neurons of the cerebral cortex are also GABAergic. Proc Natl Acad Sci USA 81:6526-6530.

Hendry SHC, Jones EG, Emson PC, Lawson DEM, Heizmann CW, Streit $P$ (1989) Two classes of cortical GABA neurons defined by differential calcium binding protein immunoreactivities. Exp Brain Res 76:467-472.

Hess R, Negishi K, Creutzfeldt O (1975) The horizontal spread of intracortical inhibition in the visual cortex. Exp Brain Res 22:415419.

Hughes CM, Peters A (1989) Do non-pyramidal neurons in rat visual cortex project across the corpus callosum? Anat Rec 223:54A.

Innocenti GM (1980) The primary visual pathway through the corpus callosum: morphological and functional aspects in the cat. Arch Ital Biol 118:124-188.

Johnson RR, Burkhalter A (1992) Evidence for excitatory amino acid neurotransmitters in the geniculo-cortical pathway and local projections within rat primary visual cortex. Exp Brain Res 89:20-30.

Jones EG (1975) Varieties and distributions of non-pyramidal cells in the somatic sensory cortex of the squirrel monkey. J Comp Neurol 160:205-268.

Katz LC, Iarovici DM (1990) Green fluorescent latex microspheres: a new retrograde tracer. Neuroscience 34:511-520.

Katz LC; Burkhalter A, Dreyer WJ (1984) Fluorescent latex microspheres as a retrograde neuronal marker for in vivo and in vitro studies of visual cortex. Nature 310:498-500.

Kisvarday ZF, Cowey A, Hodgson AJ, Somogyi P (1986) The relationship between GABA immunoreactivity and labelling by local uptake of $\left[{ }^{3} \mathrm{H}\right] \mathrm{GABA}$ in the striate cortex of the monkey. Exp Brain Res 62:89-98.

Kisvarday ZF, Martin KAC, Friedlander MJ, Somogyi P (1987) Evidence for interlaminar inhibitory circuits in striate cortex of cat. $\mathrm{J}$ Comp Ncurol 260:1-19.

Kisvarday ZF, Cowey A, Smith AD, Somogyi P (1989) Interlaminar and lateral excitatory amino acid connections in the striate cortex of monkey. J Neurosci 9:667-682.

Krieg WJ (1946) Connections of the cerebral cortex. I. The albino rat. B. Structure of the cortical areas. J Comp Neurol 84:278-323.

Lemmon V, Pearlman AL (1981) Does laminar position determine 
the receptive field properties of cortical neurons? A study of corticotectal cells in area 17 of the normal mouse and the reeler mutant. J Neurosci 1:83-93.

Lin C-S, Lu SM, Schmechel DE (1986) Glutamic acid decarboxylase and somatostatin immunoreactivities in rat visual cortex. J Comp Neurol 244:369-383.

Lund JS (1987) Local circuit neurons of macaque monkey striate cortex. I. Neurons of laminae 4C and 5A. J Comp Neurol 257:6092.

Lund JS, Hawken MJ, Parker AJ (1988) Local circuit neurons of macaque monkey striate cortex. II. Neurons of laminae $5 \mathrm{~B}$ and 6 . J Comp Neurol 276:1-29.

Martin KAC, Somogyi P, Whitteridge D (1983) Physiological and morphological properties of identified basket cells in the cat's visual cortex. Exp Brain Res 500:193-200.

Matsubara JA (1988) Local, horizontal connections within area 18 of the cat. In: Progress in brain research, Vol 75 (Hicks LP, Benedek G, eds), pp 163-172. New York: Elsevier.

Matsubara JA, Nance DM, Cynander MS (1987) Laminar distribution of GABA-immunoreactive neurons and processes in area 18 of the cat. Brain Res Bull 18:121-126.

McCormick DA, Connors BW, Lighthall JW, Prince DA (1985) Comparative electrophysiology of pyramidal and sparsely spiny stellate neurons of the neocortex. J Neurophysiol 54:782-806.

McDonald CT, Burkhalter A (1990) Extrinsic and intrinsic inhibitory connections in rat visual cortex. Soc Neurosci Abstr 16:1271.

McGuire BA, Gilbert CD, Rivlin PK, Wiesel TN (1991) Targets of horizontal connections in macaque primary visual cortex. J Comp Neurol 305:370-392

McLean IW, Nakane PK (1974) Periodate-lysine-paraformaldehyde fixative for immunoelectron microscopy. J Histochem Cytochem 22: 1077-1083.

Meinecke DL, Peters A (1987) GABA immunoreactive neurons in rat visual cortex. J Comp Neurol 261:388-404.

Miller MW, Vogt BA (1984) Heterotopic and homotopic connections in rat visual cortex. Brain Res 297:75-89.

Montero VM (1986) The interneuronal nature of GABAergic neurons in the lateral geniculate nucleus of the rhesus monkey: a combined HRP and GABA-immunocytochemical study. Exp Brain Res 64:615622.

Montcro VM, Zcmpel J (1985) Evidence for two types of GABAcontaining interneurons in the A-laminae of the cat lateral geniculate nucleus: a double-label HRP and GABA-immunocytochemical study. Exp Brain Res 60:603-609.

Naegele JR, Katz LC (1990) Cell surface molecules containing $N$ acetylgalactosamine are associated with basket cells and neurogliaform cells in cat visual cortex. J Neurosci 10:540-557.

Oertel WH, Schmechel DE, Tappaz ML, Kopin IJ (1981) Production of a specific antiserum to rat brain glutamic acid decarboxylase by injection of an antigen-antibody complex. Neuroscience 6:2689-2700.

Olavarria J, Montero VM (1984) Relation of callosal and striateextrastriate cortical connections in the rat: morphological definition of extrastriate visual areas. Exp Brain Res 54:240-252.

Olavarria J, Malach R, Van Sluyters RC (1987) Development of visual callosal conncctions in nconatally cnuclcated rats. J Comp Neurol 260:321-348.

Peters A, Kara DA (1985) The neuronal composition of area 17 of the rat visual cortex. II. The nonpyramidal cells. J Comp Neurol 234: 242-263.

Peters A, Proskauer CC, Ribak CE (1982) Chandelier cells in rat visual cortex. J Comp Neurol 206:397-416.

Peters A, Payne BR, Josephson K (1990) Transcallosal non-pyramidal cell projections from visual cortex in the cat. J Comp Neurol 302: 124-142.

Rakic P (1976) Definition of the term, "local circuit neuron," and the concept of local neuronal circuits. In: Local circuit neurons (Rakic P, ed), pp 5-20. Cambridge, MA: MIT Press.

Sandell JH, Schiller PH (1982) Effect of cooling area 18 on striate cortex cells in the squirrel monkcy. J Neurophysiol 48:38-48.

Schmued LC, Swanson LW, Sawchenko PE (1982) Some fluorescent counterstains for neuroanatomical studies. J Histochem Cytochem 30:123-128.

Schofield BR, Hallman LE, Lin S-C (1987) Morphology of corticotectal cells in primary visual cortex of hooded rats. J Comp Neurol 261:85-97.
Sillito AM (1975a) The effectiveness of bicuculline as an antagonist of GABA and visually evoked inhibition in the cat's striate cortex. J Physiol (lond) 250:287-304.

Sillito AM (1975b) The contribution of inhibitory mechanisms to the receptive field properties of neurones in the striate cortex of the cat J Physiol (Lond) 250:305-329.

Sillito AM (1977) Inhibitory processes underlying direction specificity of simple, complex and hypercomplex cells in striate cortex of the cat. J Physiol (Lond) 271:699-720.

Sillito AM (1979) Inhibitory mechanisms influencing complex cell orientation selectivity and their modification at high resting discharge levels. J Physiol (Lond) 289:33-53.

Simmons PA, Pearlman AL (1983) Receptive field properties of transcallosal visual cortical neurons in the normal and reeler mouse. $\mathbf{J}$ Neurophysiol 50:838-848.

Somogyi P, Hodgson AJ (1985) Antisera to gamma aminobutyric acid. III. Demonstration of GABA in Golgi-impregnated neurons and in conventional electron microscopic sections of cat striate cortex. $\mathrm{J}$ Histochem Cytochem 33:249-257

Somogyi P, Soltesz I (1986) Immunogold demonstration of GABA in synaptic terminals of intracellularly recorded, horseradish peroxidase filled basket cells and clutch cells in the cat's visual cortex. Neuroscience 19:1051-1065.

Somogyi P, Cowey A, Halasz N, Freund TF (1981) Vertical organization of neurons accumulating $\left[{ }^{3} \mathrm{H}\right] \mathrm{Gaba}$ in visual cortex of rhesus monkey. Nature 294:761-763.

Somogyi P, Cowey A, Kisvarday ZF, Freund TF, Szentagothai J (1983a) Retrograde transport of $\left[{ }^{3} \mathrm{H}\right]$-GABA reveals specific interlaminar connections in the striate cortex of monkey. Proc Natl Acad Sci USA 80: 2385-2389.

Somogyi P, Kisvarday ZF, Martin KAC, Whitteridge D (1983b) Synaptic connections of morphologically identified and physiologically characterized large basket cells in the striate cortex of the cat. Neuroscience 10:261-294.

Somogyi P, Freund TF, Kisvarday $Z$ (1984) Different types of ${ }^{3} \mathrm{HGABA}$ accumulating neurons in the visual cortex of the rat. Characterization by combined autoradiography and Golgi impregnation. Exp Brain Res 54:45-56.

Streit P (1980) Selective retrograde labeling indicating the transmitter of neuronal pathways. J Comp Neurol 191:429-463.

Swadlow HA (1974) Properties of antidromically activated callosal neurons and neurons responsive to callosal input in rabbit binocular cortex. Exp Neurol 43:424-444.

Thomas HC, Espinoza SG (1987) Relationships between interhemispheric cortical connections and visual areas in hooded rats. Brain Res 417:214-224.

Tiao Y-C, Blakemore C (1976) Functional organization in the visual cortex of the golden hamster. J Comp Neurol 168:459-482.

T's'o D, Charles CD, Wiesel TN (1986) Relationship between horizontal interactions and functional architecture in cat striate cortex as revealed by cross-correlation analysis. J Neurosci 6:1160-1170.

Tsumoto T, Eckart W, Creutzfeldt OD (1979) Modification of orientation sensitivity of cat visual cortex neurones by GABA mediated inhibition. Exp Brain Res 46:157-169.

Valverde F (1976) Aspects of cortical organization related to the geometry of neurons with intra-cortical axons. J Neurocytol 5:509-529.

Vogt BA, Gorman ALF (1982) Responses of cortical neurons to stimulation of corpus callosum in vitro. J Neurophysiol 48:1257-1273.

Voigt T, LeVay S, Stamnes MA (1988) Morphological and immunocytochemical observations on the visual callosal projections in the cat. J Comp Neurol 272:450 460.

Welker C, Woolsey TA (1974) Structure of layer IV in the somatosensory neocortex of the rat: description and comparison with the mouse. J Comp Neurol 158:437-454.

Werner L, Hedlich A, Winkelmann E, Brauer K (1979) Versuch einer Identifizierung von Nervenzellen des visuellen Kortex der Ratte nach Nissl- und Golgi-Kopsch-Darstellung. J Hirnforsch 20:121-139.

Werner L, Hedlich A, Winkelmann E (1985) Neuronentypen im visuellen Kortex der Ratte, identifiziert in Nissl- und deimprägnierten Golgi-Präparaten. J Hirnforsch 26:173-186.

Zaremba S, Naegele JR, Barnstable CJ, Hockfield S (1990) Neuronal subsets express multiple high-molecular-weight cell-surface glycoconjugates defined by monoclonal antibodies Cat 301 and VC1.1. J Neurosci 10:2985-2995. 